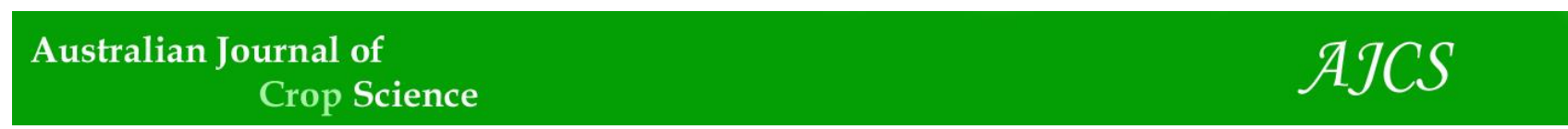

AJCS 13(01):170-178 (2019)

ISSN:1835-2707

doi: 10.21475/ajcs.19.13.01.p1778

\title{
Drought tolerance indices for selection of drought tolerant, high yielding upland rice genotypes
}

\author{
Yosep S. Mau", Antonius S.S. Ndiwa, Shirly S. Oematan, Jenny E.R. Markus \\ Faculty of Agriculture, Universitas Nusa Cendana, Jl. Adisucipto, Penfui, Kupang, NTT 85001 Indonesia
}

*Corresponding Author: yosepmau@yahoo.com

\section{Abstract}

The purposes of this study were (1) to assess the effectiveness of drought tolerance indices for selection of drought tolerance in upland rice, and (2) to identify the most suitable drought tolerance indices to select for drought tolerant, high yielding upland rice genotypes. This study employed a Split Plot design consisting of irrigation levels as the main plots, and rice genotype as the sub-plot treatments. There were three main plots: $100 \%$ field capacity (FC); $75 \%$ FC; and 50\% FC level. The subplot treatments consisted of 40 upland rice genotypes. Grain yields under no-stress and stressed conditions were used to calculate drought tolerance indices. There were significant variations in grain yields and drought tolerance indices between different rice genotype treatments. The indices from the literature found to be most suitable for the selection of drought tolerant upland rice cultivars were STI, GMP, MRP, HARM, REI, ATI, YI, SNPI. Ten genotypes from among the 40 tested - namely HK-07, ADN-04, PMK-01, ADN-05, NGR-022, ALR-02, HK-06, and KMD-01 - were selected as combining drought tolerance with high yield potential.

Keywords: upland rice, genotypes, drought tolerance index, grain yield.

Abbreviations: SSI_stress susceptibility index; RDI_relative drought index; STI_stress tolerance index; MP_mean productivity; DRI_drought response index; GMP_geometric mean productivity; REI_relative efficiency index; MRP_mean relative performance; MISTIk1_modified STI1; MISTIK2_modified STI2; ATI_abiotic tolerance index; SSPI_stress susceptibility percentage index; SNPI_stress/non-stress production index; HRM_harmonic mean yield; RDY_relative decrease in yield.

\section{Introduction}

One of the major abiotic stresses influencing crop productivity is water deficit. This effect is more pronounced in crops such as rice that mainly completes its life cycle under water saturated condition. Water stress is, therefore, a major abiotic constraint for rice productivity worldwide, most notably in Asia (Bray et al., 2000; Kumbhar et al., 2015). Diminishing water supplies for agriculture worldwide is an increasing trend. This necessitates the search for drought adaptation in crops like rice. Screening for rice varieties that are tolerant of water stress is seen as an important step in sustaining future development of rice production (Pandey and Shukla, 2015).

Selection of drought tolerance is more urgent for upland rice than for lowland, fully irrigated rice. Upland rice is generally cultivated under water-unsaturated conditions, especially during the recent phenomena of prolonged droughts due probably to global climate change (Halliwell, 2006). Improvement of rice adaptation to drought, via selection of drought-tolerant varieties, relies on the availability of a gene pool for the desired traits. Upland rice germplasm is an invaluable genetic resource that can be employed for improvement of drought tolerance.

Improvement of drought tolerance requires an understanding of plant diversity in relation to adaptation to drought (Alonso-Blanco et al., 2009), followed by design of the most effective selection strategy for plant survival and productivity under conditions of moisture-stress (Sarkar et al., 2013). Evaluation of genotypic variability under different moisture stress conditions is an essential step for a successful breeding program focused on drought tolerance (Abenavoli et al., 2016; Anower et al., 2015).

A collection of pigmented upland rice germplasm from East Nusa Tenggara, Indonesia has previously been evaluated for genetic diversity (Mau et al., 2017) and for resistance to blast (Mau et al., 2018). Pigmented rice with red and black/purple pericarp is rich in carbohydrate, protein, vitamins, mineral content, and also anthocyanins, which confer various health-promoting properties (Tsuda et al., 2002; Hyun et al., 2004; Nam et al., 2006; Shao et al., 2011). This germplasm collection represents a gene pool that can be explored for selection and improvement of drought tolerance in upland rice, as well as for the production of superior pigmented upland rice cultivars that are currently of limited availability in Indonesia (Santika and Rozakurniati, 2010; IAARD, 2012) and perhaps in other parts of the world as well.

Some studies have investigated the use of osmo-priming compounds such $\mathrm{NaCl}, \mathrm{KCl}$ or polyethylene glycol (PEG) to assess the effect of soil moisture stress on seed germination and on seedling growth (Islam et al., 2012; Singh et al., 2017a; Swapna and Shylaraj 2017; Mishra and Panda 2017). These priming methods, require specific standard methods to validate the moisture stress generated under field conditions (Singh et al., 2017b). Other studies on drought 
resistance in rice have frequently used indirect selection indicators such as morphological and physiological responses (Fukai and Cooper 1995; Rahman et al., 2002; Yue et al., 2006; Farooq et al., 2010; Kumar et al., 2015; Singh et al., 2017b; Purbajanti et al., 2017). Nevertheless, such indirect selection methods are more labor and resource intensive, as many characters need to be evaluated and the selected tolerant genotypes may not necessarily be high yielding. For this reason, selection for drought tolerance based on indices developed from grain yield is considered a more rapid and effective approach to selecting genotypes that combine drought tolerance with general high yield potential.

Many indices of drought tolerance have previously been proposed for use in selection of drought tolerant genotypes in various crops. These indices include stress susceptibility index (SSI) (Fischer and Maurer, 1978); relative drought index (RDI) (Fischer and Wood, 1979); mean productivity (MP) (Rosielle and Hamblin, 1981); drought response index (DRI) (Bidinger et al., 1987); stress tolerance index (STI) and geometric mean productivity (GMP) (Fernandez 1992); relative efficiency index (REI) and mean relative performance (MRP) (Hossain et al., 1999; modified STI1 (MISTIk1) and modified STI2 (MSTIK2) (Farshadfar and Sutka, 2002). More recently, proposals for indices of drought tolerance have included abiotic tolerance index (ATI), stress susceptibility percentage index (SSPI), and stress/non-stress production index (SNPI) (Moosavi et al., 2008); harmonic mean yield (HARM) (Dadbakhsh et al., 2011); and relative decrease in yield (RDY) (Farshadfar and Elyasi, 2012).

In summary, to date, more than 20 indices have been employed for selection of drought-tolerant varieties, with varying degree of effectiveness depending on the particular crop species. Among these, STI, SSI, MP, MRP, HARM, REI, ATI, GMP, MSTIK1, MSTIK2, SNPI, SSPI, YI, RDI, and RDY have previously been reported to be the most suitable indices for various crops (Naghavi et al., 2003; Sio-Se et al., 2006; Moosavi et al., 2008; Bahar and Yildirim, 2010; Golbashy et al., 2010; Dadbakhsh et al., 2011; Farshadfar and Elyasi, 2012; Mau et al., 2014; Ali and El-Sadek, 2016; Bennani et al., 2017) but these have not been assessed in upland rice. Thus, the purposes of the study reported in this paper were (1) to assess the effectiveness of drought tolerance indices for selection of drought tolerance in upland rice, and (2) to determine the most suitable index for identifying drought tolerant, high-yielding upland rice genotypes.

\section{Results}

\section{Grain yield and drought tolerance indices}

The grain yield was recorded from rice plots grown under non-stressed $(100 \%$ field capacity $(\mathrm{FC})$ and drought-stressed conditions (75\% FC/Stress Level 1 and 50\% FC/Stress Level 2). Two-way ANOVA (Table 1) showed that there were highly significant differences in grain yield between genotypes $(P<0.001)$ under both non-stressed and stressed conditions. The mean grain yield under no stress conditions was the highest ( $3.43 \mathrm{t} / \mathrm{ha}$ ) (Table 2), which can be considered as the potential yield (YP). The mean yield at $75 \%$ FC ( $2.66 \mathrm{t} / \mathrm{ha})$ was $22 \%$ lower than the potential yield while that at $50 \% \mathrm{FC}$ ( $2.28 \mathrm{t} / \mathrm{ha}$ ) was $34 \%$ lower than the potential yield. The stress intensity at $75 \%$ FC (SL 1) was, therefore, considered mild with a stress intensity value of 0.22 while that at $50 \%$ FC (SL 2) was considered moderate with a stress intensity level of 0.34 .

Interaction between drought stress level (SL) and genotype (G) affected all drought indices either significantly or highly significantly. Five drought tolerance indices, i.e. REI, ATI, SNPI and YSI differed between the two stress levels (SL1 0.22 and SL2 0.34), whereas the drought indices STI, GMP, MRP, HARM, MP, YI, MSTIK1, RDI, SSI and MSTIK2 were stable across the two stress levels. As there was no real difference in grain yield (YS) between SL1 and SL2, and because most of the drought indices were stable across the two stress levels, only the data from the higher stress level (SL2 with 0.34 /moderate stress intensity) was used for the evaluation described below in the rest of this paper.

Drought tolerance indices and grain yield under nonstressed and moderately stressed conditions (SL2 0.34) are presented in Table 2. Table 2 shows that the grain yield for genotypes under no-stress conditions ranged from 1.73 to $7.39 \mathrm{t} \mathrm{ha}^{-1}$ (mean of $3.43 \mathrm{t} \mathrm{ha}^{-1}$ ) while that at 0.34 stress intensity ranged from 1.33 to $3.88 \mathrm{t} \mathrm{ha}^{-1}$ (mean of $2.28 \mathrm{t} \mathrm{ha}^{-1}$ ). Based on a ranking method and a $25 \%$ selection intensity, ten best genotypes were selected: i.e. ADN-04, HK-07, PMK01, SBD-02, ADN-05, ISN-03, SBD-04, MGR-04, NGR-022, and HK-06. Interestingly, nine of these ten genotypes, i.e. all except SBD-02, ranked among the best ten within each of the drought indices STI, GMP, MRP, HARM, and ATI and in grain yield (YP and YS). Of the remaining indices, seven genotypes were selected by REI, four genotypes by $\mathrm{YI}$ and MSTIK1, and two genotypes by SNPI.

\section{Correlation among yield and drought tolerance indices}

Table 3 shows the coefficients of correlation among grain yield and drought tolerance indices under 0.34 stress levels. Yield (YP) under non-stressed conditions was highly correlated with yield (YS) under 0.34 stress level. YP and YS were also highly significantly and positively associated with drought indices STI, GMP, MRP, HARM, MP, REI, and ATI at 0.34 stress level (Table 3 ). At the moderate drought stress level (0.34), correlation between each of the drought indices YI, MISTIK1, SSPI, and SSI was significant only with YP. A similar situation was found for the indices SNPI and MISTIK2 but the direction of the correlation was negative. YS and RDI were negatively correlated with YS but their correlations with YP were absent at 0.34 stress level.

Under the 0.34 stress level, a perfect correlation was found between drought indices STI, GMP, MRP, HARM, and MP. A similar tight correlation was found between another cluster of drought indices: YI, MSTIK1, SSPI, and RDI. SSPI was significantly and negatively correlated with almost all indices. As with SSPI, MISTK2 also showed significant and negative correlation with other indices, except with HARM. SSI had a significant and positive correlation with other indicators but its correlation with SNPI was negative.

\section{Principal component analysis}

Results of Principal Component Analysis (PCA) applied to the variables in the correlation coefficient matrix revealed that two principal components explained $96.79 \%$ variations for drought tolerance indices. The first component explained 
about $62.99 \%$ and the second explained $33.80 \%$ of the observed variations.

The results also showed that PC1 was positively correlated with almost all drought indices, except SNPI and MSTIK2 which were negative (Fig 1). PC2 had a positive relationship with drought indices STI, GMP, MP, HARM, MRP, ATI, SNPI and MSTIK2 and a negative relationship with YI, YSI, MSTIK1, RDI, and SSI, while its relationship with REI and SSPI was negligible.

The biplot diagram (Fig 1) shows that drought indices STI, GMP, GM, HARM, ATI, and MRP were the best indices to select for drought tolerant genotypes with high and stable grain yield, i.e. genotypes 29 (HK-07), 31 (KMD-01), 38 (ADN05), 22 (NGR-22), 4 (ALR-02) and 6 (ADN-04).

\section{Discussion}

This study revealed a decrease in mean grain yield of $34 \%$ in the drought-stressed main plot in which soil moisture declined to $50 \%$ field capacity level in the post flowering stage of the rice life cycle, relative to the unstressed main plot treatment in which irrigation ensured field capacity through until harvest. Decrease of grain yield due to drought stress in cereal crops has been reported previously by many workers (Rahman et al., 2002; Yue et al., 2006; Golabadi et al., 2006; Moosavi et al., 2008; Dadbakhsh et al., 2011; Farshadfar and Elyasi, 2012; Dixit et al., 2014; Bennani et al., 2017). The drought stress-induced grain yield reduction reported here was of moderate level. Moderate drought stress is reported to be suitable for selecting droughttolerant genotypes in wheat (Ali and El-Sadek, 2016).

Under the level of moderate stress (SL2: 0.34 stress level), ten best genotypes (HK-06, HK-07, ADN-04, KMD-01, ALR-01, PMK-01, NGR-022, ADN-05, MGP-01, and SBD-02) were selected based on mean rank of grain yield. Seven of these genotypes were among the best ten genotypes in the drought indices STI, GMP, MRP, HARM, REI, ATI, YI, SNPI and in grain yields YP and YS. These findings imply that selecting drought tolerant genotypes based on mean rank of multiple drought indices is effective but additional methods of selection based on correlation analysis, principal component analysis, and bi-plot diagram may need to be included to make the selection more effective. A previous study by Farshadfar and Elyasi (2012) successfully used a mean-rank method in combination with correlation analysis, and Principal Component Analysis to select for drought tolerant genotypes of bread wheat landraces. Drought indices such as STI, MP, GMP, MRP, HARM, RDI, ATI, REI, and MISTIK1 have also been reported to be effectively used to select drought tolerant, high yielding genotypes in various crops (Dadbakhsh et al., 2011; Farshadfar and Elyasi, 2012; Naghavi et al., 2013; Ali and El-Sadek, 2016; Bennani et al., 2017).

Results in this study indicated a positive and highly significant correlation between $\mathrm{YP}$ and $\mathrm{YS}$ under moderate/0.34 stress level, suggesting that genotypes that showed high grain yield under non-stressed condition also demonstrated high yield under stressed condition. A positive correlation between YP and YS has also been reported in earlier studies (Moosavi et al., 2008; Dadbakhsh et al., 2011; Naghavi et al., 2013; Bennani et al., 2017). The drought indices STI, GMP, MRP, HARM, MP, REI and ATI also showed highly significant correlations with YP and YS, which suggests that the drought indices are able to identify high yielding genotypes under non-stressed and stressed conditions. The same drought indices were also previously reported by Bennani et al. (2017) to have a positive and high correlation with YP and YS in bread wheat. Farshadfar and Elyasi (2012) and Moosavi et al. (2008) also observed a positive and significant correlation between YP and YS with STI, GMP, $\mathrm{MP}, \mathrm{ATI}$, and other indices in bread wheat. Positive and significant correlation between STI, GMP and MP with YP and YS have also been previously reported by other workers (Golabadi et al., 2006; Jafari et al., 2009; ilker et al., 2011; Toorchi et al., 2012). The high correlations between YP, YS and drought indices may serve as good indicators for selection of the best indices and the best genotypes. Drought indices having a significant correlation with grain yield in both non-stressed and stressed conditions are reported to be suitable for selecting drought tolerant genotypes (Mitra, 2001).

A perfect correlation was observed between drought indices STI, GMP, MRP, HARM, and MP; near perfect correlations occurred also for another cluster of drought indices $\mathrm{YI}$, MSTIK1, SSPI, and RDI. The results suggest that drought indices that show perfect correlation can perhaps be used interchangeably. Interchangeable drought indices have also been reported in wheat by Ali and El-Sadek (2016) and Bennani et al. (2017).

Drought indices showing positive and significant correlation with YP and YS, i.e., STI, GMP, MRP, HARM, MP, REI, and ATI were also the indices that selected the ten best genotypes based on mean-rank of all employed drought indices and YP and YS. Thus STI, GMP, MRP, HARM, MP, REI, and ATI are suitable indices to select for drought tolerant and high yielding upland rice genotypes. As with ranking method, correlation analysis, PC analysis, and bi-plot diagram showed that the drought indices STI, GMP, GM, HARM, ATI, MRP, and REI are the most suitable indices to select for drought tolerant genotypes.

Upland rice genotypes number 29 (HK-07), 6 (ADN-04), 37 (PMK-01), 38 (ADN-05), 22 (NGR-22), and 4 (ALR-02) were selected as the best genotypes based on drought indices STI, GMP, GM, HARM, ATI, and MRP. Interestingly, six (HK-07, ADN-04, PMK-01, ADN-05, NGR-022, and ALR-02) among the seven selected genotypes were also selected based on the ranking method using drought indices STI, GMP, MRP, HARM, REI, ATI, YI, SNPI. The present study results were in line with the results of previous workers (Dadbakhsh et al., 2011; Farshadfar and Elyasi, 2012; Naghavi et al., 2013; Ali and El-Sadek, 2016; Bennani et al., 2017) where the drought indices STI, GMP, MRP, HARM, REI, ATI, YI, SNPI have also been reported to be the most suitable for selecting for drought tolerant genotypes in various crops.

Overall, the present study results revealed that drought indices STI, GMP, GM, HARM, ATI, MRP, REI, YI, and SNPI are the most suitable drought indices to select for drought tolerant upland rice genotypes. By considering various methods of selection employing these multiple drought indices, eight upland rice genotypes were selected, i.e., HK07, ADN-04, PMK-01, ADN-05, NGR-022, ALR-02, HK-06, and KMD-01. These genotypes are drought tolerant and also high yielding in both non-stressed and moderate drought-stress conditions. All these are pigmented (red and black/purple pericarp) upland rice genotypes (Mau et al., 2017; Mau et al., 2018), while four of them (ADN-04, KMD-01, HK-06, 
Table 1. Results from analyses of variance of grain yield and of estimated indices of drought tolerance for 40 upland rice genotypes grown under three different soil moisture regimes (nonstressed; mildy stressful SL1 0.22; and moderately stressful S12 0.34); mean squares for soil moisture regimes for genotypes, and for their interactior

\begin{tabular}{|c|c|c|c|c|c|c|}
\hline \multirow[t]{3}{*}{ Source of Variation } & \multicolumn{3}{|l|}{ Two-way ANOVA } & \multirow{3}{*}{$\begin{array}{l}\text { ANOVA } \\
\text { SLO: No stress } \\
\text { Genotype Effect }\end{array}$} & \multirow{3}{*}{$\begin{array}{l}\text { ANOVA } \\
\text { SL1: } 0.22 \\
\text { Genotype Effect }\end{array}$} & \multirow{3}{*}{$\begin{array}{l}\text { ANOVA } \\
\text { SL2: } 0.34 \\
\text { Genotype Effect }\end{array}$} \\
\hline & & & & & & \\
\hline & Stress level (SL) & Genotype (G) & $S L \times G$ & & & \\
\hline Grain Yield (YP and YS) & $27.5239^{* * *}$ & $4.0110^{* * *}$ & $0.4336^{* *}$ & $2.6518^{* * *}$ & - & - \\
\hline Grain Yield (YS) & 5.9287 & $1.9124^{* *}$ & $0.3140^{* *}$ & & $1.5532^{* *}$ & $0.6773^{* *}$ \\
\hline GMP & 2.2328 & $2.9556^{* * *}$ & $0.1207^{* *}$ & & $1.9200^{* *}$ & $1.1594^{* *}$ \\
\hline MRP & 0.0001 & $1.4040^{* * *}$ & $0.0427^{* *}$ & & $0.8434^{* *}$ & $0.6021^{* *}$ \\
\hline HARM & 3.0562 & $2.7560^{* * *}$ & $0.1686^{* *}$ & & $1.8841^{* *}$ & $1.0397^{* *}$ \\
\hline MP & 1.4822 & $3.1931^{* * *}$ & $0.0785^{* *}$ & & $1.9573^{* *}$ & $1.3139^{* *}$ \\
\hline REI & $24.2597^{*}$ & $0.9331^{* *}$ & $0.4088^{*}$ & & $1.2646^{* *}$ & $0.0786^{* *}$ \\
\hline ATI & $46.9413^{* *}$ & $5.7792^{* *}$ & $2.3337^{* *}$ & & $7.4649^{* *}$ & $0.6507^{* *}$ \\
\hline YI & 0.0001 & $0.4527^{* *}$ & $0.2010^{* *}$ & & $0.2196^{* *}$ & $0.4340^{* *}$ \\
\hline MSTIK1 & 1.8474 & $0.2767^{* *}$ & $0.1155^{* *}$ & & $0.0939^{* *}$ & $0.2977^{* *}$ \\
\hline SNPI & $1139.5062^{*}$ & $13.9499^{* *}$ & $13.5995^{* *}$ & & $26.3757^{* *}$ & $1.1737^{* *}$ \\
\hline SSPI & $46.9413^{* * *}$ & $5.7702^{* *}$ & $2.3337^{* *}$ & & $7.469^{* *}$ & $0.6507^{* *}$ \\
\hline YSI & $8.7473^{*}$ & $0.0209^{* *}$ & $0.0506^{* *}$ & & $0.0283^{* *}$ & $0.0437^{* *}$ \\
\hline RDI & 11.2912 & $0.0437^{* *}$ & $01016^{* *}$ & & $0.0465^{* *}$ & $0.0990^{* *}$ \\
\hline SSI & 0.1781 & $0.6057^{* *}$ & $0.2347^{* *}$ & & $0.5267^{* *}$ & $0.3153^{* *}$ \\
\hline MSTIK2 & 2.9241 & $0.1992^{* *}$ & $0.0833^{*}$ & & $0.0774^{* *}$ & $0.2053^{* *}$ \\
\hline
\end{tabular}

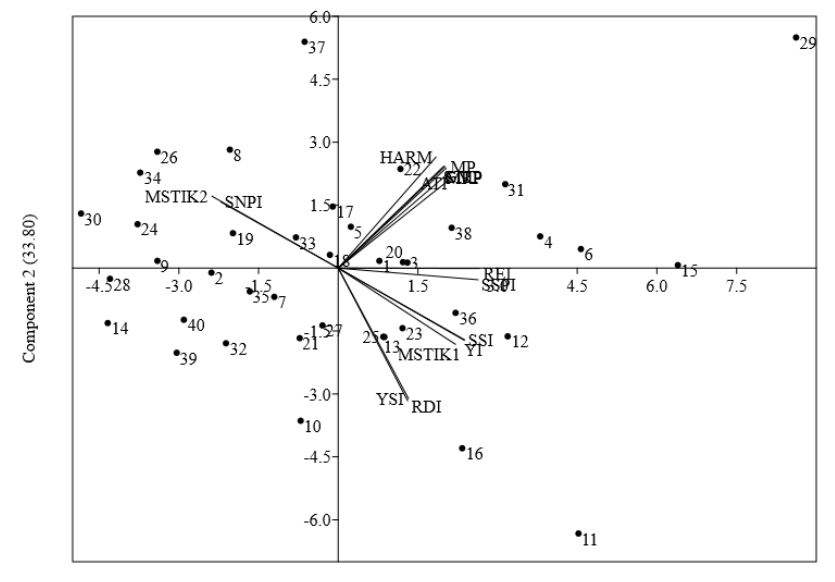

Component $1(62.99 \%)$

Fig 1. Biplot diagram for drought tolerance indices in 0.34 stress level. (Genotypes - 1:ADN-03, 2:TLB-04, 3:SBD-02, 4: ALR-01, 5:NGR-01, 6:ADN-04, 7:P.WANGI, 8:SBD-04, 9:SBR-01,10:CBL-01, 11:PJ-01, 12:MANU-04, 13:SLR-07, 14:TLB-04, 15:HK-06, 16:TLB-02, 17:SBD-03, 18:MGR-04, 19:NGR-21, 20:WTN-21, 21:WTN-22, 22:NGR-22: 23:PAU-01, 24:SBD-05, 25:ISN-03, 26:ISN-02, 27:PM-01, 28:BLU-01, 29:HK-07, 30:SLT-01, 31:KMD-01, 32:SBD-01, 33:G.MUNGKUR, 34:AEK SIBUND., 35:ALR-02, 36:MGP-01, 37:PMK-01,38: ADN-05, 39:SBD-12, 40.IR-20) 
Table 2. Mean grain yield and drought tolerance indices for 40 upland rice genotypes grown under non-stressed conditions (i.e. on soils at field capacity throughout) and under moderately stressed conditions (on soils at $50 \%$ field capacity during the post flowering phase of plant development).

\begin{tabular}{|c|c|c|c|c|c|c|c|c|c|c|c|c|c|c|c|c|c|}
\hline Genotype & YP & YS & STI & GMP & $\begin{array}{l}\mathrm{MR} \\
\mathrm{P}\end{array}$ & $\begin{array}{l}\text { HAR } \\
M\end{array}$ & MP & REI & ATI & YI & MSTIK1 & SNPI & SSPI & YSI & RDI & SSI & MSTIK2 \\
\hline ADN-03 & 3.66 & 2.4 & 0.75 & 2.96 & 2.12 & 2.9 & 3.03 & 0.37 & 1.05 & 1.12 & 1.52 & 4.41 & 18.3 & 0.32 & 0.49 & 0.96 & 1.49 \\
\hline TLB-05 & 2.55 & 2.01 & 0.44 & 2.27 & 1.63 & 2.25 & 2.28 & 0.17 & 0.6 & 0.7 & 1.27 & 5.33 & 7.89 & 0.26 & 0.39 & 0.59 & 1.8 \\
\hline SBD-02 & 3.84 & 2.44 & 0.8 & 3.06 & 2.19 & 2.98 & 3.14 & 0.4 & 1.1 & 1.2 & 1.58 & 4.3 & 20.5 & 0.34 & 0.51 & 1.03 & 1.44 \\
\hline ALR-01 & 4.93 & 2.67 & 1.11 & 3.61 & 2.61 & 3.44 & 3.8 & 0.59 & 1.54 & 1.45 & 1.86 & 3.99 & 32.9 & 0.35 & 0.53 & 1.26 & 1.24 \\
\hline NGR-01 & 3.66 & 2.58 & 0.8 & 3.07 & 2.2 & 3.02 & 3.12 & 0.32 & 1.07 & 0.94 & 1.43 & 4.79 & 15.7 & 0.27 & 0.41 & 0.82 & 1.6 \\
\hline ADN-04 & 5.16 & 2.61 & 1.15 & 3.67 & 2.65 & 3.47 & 3.88 & 0.65 & 1.59 & 1.62 & 1.97 & 3.79 & 37.1 & 0.38 & 0.57 & 1.38 & 1.16 \\
\hline P. WANGI & 2.81 & 2.03 & 0.48 & 2.39 & 1.71 & 2.35 & 2.42 & 0.24 & 0.68 & 0.92 & 1.39 & 4.78 & 11.5 & 0.33 & 0.5 & 0.78 & 1.64 \\
\hline SBD-04 & 3.34 & 2.88 & 0.82 & 3.1 & 2.24 & 3.09 & 3.11 & 0.15 & 0.92 & 0.45 & 1.16 & 6.25 & 6.64 & 0.12 & 0.19 & 0.38 & 1.96 \\
\hline SBR-01 & 2.3 & 1.94 & 0.38 & 2.11 & 1.52 & 2.1 & 2.12 & 0.12 & 0.5 & 0.52 & 1.19 & 5.9 & 5.35 & 0.21 & 0.32 & 0.45 & 1.91 \\
\hline CBL-01 & 2.36 & 1.47 & 0.29 & 1.86 & 1.33 & 1.81 & 1.92 & 0.25 & 0.34 & 1.22 & 1.62 & 4.27 & 13.1 & 0.57 & 0.86 & 1.06 & 1.41 \\
\hline PJ-01 & 3.97 & 1.33 & 0.45 & 2.29 & 1.74 & 1.98 & 2.65 & 0.55 & 0.28 & 2.19 & 3 & 3.29 & 38.6 & 0.81 & 1.22 & 1.86 & 0.77 \\
\hline MANU-04 & 4.24 & 2.12 & 0.77 & 2.99 & 2.17 & 2.82 & 3.18 & 0.54 & 1.03 & 1.65 & 2.01 & 3.76 & 30.9 & 0.47 & 0.71 & 1.41 & 1.14 \\
\hline SLR-07 & 3.34 & 2 & 0.57 & 2.58 & 1.86 & 2.5 & 2.67 & 0.37 & 0.77 & 1.33 & 1.68 & 4.14 & 19.6 & 0.44 & 0.66 & 1.12 & 1.37 \\
\hline TLB-04 & 1.73 & 1.42 & 0.21 & 1.56 & 1.13 & 1.55 & 1.57 & 0.09 & 0.23 & 0.52 & 1.23 & 6.9 & 4.38 & 0.31 & 0.47 & 0.47 & 1.88 \\
\hline HK-06 & 5.92 & 2.54 & 1.27 & 3.86 & 2.84 & 3.53 & 4.23 & 0.79 & 1.71 & 1.85 & 2.38 & 3.56 & 49.4 & 0.42 & 0.63 & 1.6 & 0.97 \\
\hline TLB-02 & 3.39 & 1.58 & 0.46 & 2.31 & 1.68 & 2.15 & 2.48 & 0.45 & 0.47 & 1.76 & 2.15 & 3.65 & 26.5 & 0.65 & 0.98 & 1.5 & 1.06 \\
\hline SBD-03 & 3.65 & 2.69 & 0.83 & 3.13 & 2.24 & 3.08 & 3.17 & 0.29 & 1.08 & 0.84 & 1.37 & 5.04 & 14 & 0.24 & 0.36 & 0.74 & 1.67 \\
\hline MGR-04 & 3.37 & 2.39 & 0.7 & 2.84 & 2.03 & 2.8 & 2.88 & 0.3 & 0.92 & 0.95 & 1.43 & 4.74 & 14.3 & 0.3 & 0.46 & 0.83 & 1.6 \\
\hline NGR-21 & 2.89 & 2.31 & 0.57 & 2.59 & 1.86 & 2.57 & 2.6 & 0.19 & 0.76 & 0.65 & 1.25 & 5.44 & 8.41 & 0.22 & 0.33 & 0.56 & 1.82 \\
\hline WTN-21 & 3.83 & 2.42 & 0.79 & 3.04 & 2.18 & 2.96 & 3.13 & 0.4 & 1.08 & 1.17 & 1.59 & 4.37 & 20.4 & 0.33 & 0.51 & 1.02 & 1.44 \\
\hline WTN-22 & 2.77 & 1.86 & 0.44 & 2.27 & 1.62 & 2.22 & 2.31 & 0.27 & 0.59 & 1.07 & 1.49 & 4.5 & 13.2 & 0.41 & 0.62 & 0.92 & 1.52 \\
\hline NGR-22 & 4.21 & 3.01 & 1.08 & 3.56 & 2.55 & 3.51 & 3.61 & 0.37 & 1.44 & 0.94 & 1.4 & 4.74 & 17.5 & 0.23 & 0.34 & 0.8 & 1.63 \\
\hline PAU-01 & 3.51 & 2.07 & 0.62 & 2.69 & 1.93 & 2.6 & 2.79 & 0.4 & 0.84 & 1.35 & 1.69 & 4.1 & 21 & 0.43 & 0.65 & 1.15 & 1.34 \\
\hline SBD-05 & 2.41 & 2.11 & 0.43 & 2.25 & 1.63 & 2.25 & 2.26 & 0.1 & 0.52 & 0.4 & 1.14 & 6.62 & 4.39 & 0.15 & 0.23 & 0.35 & 1.99 \\
\hline ISN-03 & 3.33 & 2 & 0.57 & 2.58 & 1.85 & 2.5 & 2.67 & 0.37 & 0.77 & 1.32 & 1.67 & 4.14 & 19.4 & 0.44 & 0.66 & 1.12 & 1.37 \\
\hline ISN-02 & 2.96 & 2.69 & 0.68 & 2.82 & 2.05 & 2.82 & 2.83 & 0.09 & 0.66 & 0.3 & 1.1 & 7.51 & 4.02 & 0.09 & 0.14 & 0.26 & 2.06 \\
\hline PM-01 & 2.98 & 1.96 & 0.5 & 2.41 & 1.73 & 2.36 & 2.47 & 0.3 & 0.68 & 1.13 & 1.53 & 4.45 & 14.9 & 0.4 & 0.59 & 0.95 & 1.51 \\
\hline BLU-01 & 1.92 & 1.67 & 0.27 & 1.79 & 1.29 & 1.79 & 1.8 & 0.09 & 0.36 & 0.44 & 1.15 & 6.28 & 3.74 & 0.21 & 0.32 & 0.37 & 1.97 \\
\hline HK-07 & 7.39 & 3.88 & 2.44 & 5.35 & 3.86 & 5.09 & 5.64 & 0.92 & 3.34 & 1.56 & 1.91 & 3.84 & 51.3 & 0.25 & 0.38 & 1.34 & 1.19 \\
\hline SLT-01 & 2.17 & 2 & 0.37 & 2.08 & 1.51 & 2.08 & 2.08 & 0.06 & 0.39 & 0.25 & 1.08 & 7.62 & 2.47 & 0.11 & 0.16 & 0.22 & 2.1 \\
\hline KMD-01 & 4.84 & 2.98 & 1.23 & 3.8 & 2.72 & 3.68 & 3.91 & 0.52 & 1.69 & 1.25 & 1.63 & 4.23 & 27.1 & 0.28 & 0.43 & 1.08 & 1.4 \\
\hline SBD-01 & 2.26 & 1.66 & 0.32 & 1.94 & 1.39 & 1.92 & 1.96 & 0.19 & 0.44 & 0.88 & 1.36 & 4.87 & 8.81 & 0.39 & 0.58 & 0.75 & 1.67 \\
\hline G. MUNG. & 3.25 & 2.42 & 0.67 & 2.8 & 2.01 & 2.77 & 2.83 & 0.26 & 0.91 & 0.84 & 1.34 & 4.96 & 12.1 & 0.26 & 0.38 & 0.72 & 1.7 \\
\hline A. SIBUN. & 2.76 & 2.48 & 0.58 & 2.62 & 1.9 & 2.61 & 2.62 & 0.1 & 0.58 & 0.31 & 1.12 & 7.82 & 4.11 & 0.11 & 0.16 & 0.28 & 2.04 \\
\hline ALR-02 & 2.69 & 1.99 & 0.46 & 2.32 & 1.66 & 2.29 & 2.34 & 0.21 & 0.63 & 0.85 & 1.35 & 4.96 & 10.2 & 0.31 & 0.46 & 0.72 & 1.7 \\
\hline MGP-01 & 3.96 & 2.71 & 0.91 & 3.28 & 2.35 & 3.22 & 3.34 & 0.37 & 1.26 & 1.03 & 1.46 & 4.57 & 18.2 & 0.27 & 0.41 & 0.88 & 1.56 \\
\hline PMK-01 & 4.33 & 3.85 & 1.42 & 4.08 & 2.96 & 4.07 & 4.09 & 0.16 & 1.31 & 0.36 & 1.12 & 6.73 & 6.95 & 0.08 & 0.11 & 0.31 & 2.02 \\
\hline ADN-05 & 4.29 & 2.67 & 0.98 & 3.39 & 2.43 & 3.29 & 3.48 & 0.46 & 1.36 & 1.24 & 1.6 & 4.25 & 23.6 & 0.31 & 0.47 & 1.05 & 1.42 \\
\hline SBD-12 & 1.93 & 1.49 & 0.24 & 1.69 & 1.22 & 1.68 & 1.71 & 0.14 & 0.31 & 0.73 & 1.31 & 5.36 & 6.5 & 0.39 & 0.59 & 0.64 & 1.74 \\
\hline
\end{tabular}




\begin{tabular}{|c|c|c|c|c|c|c|c|c|c|c|c|c|c|c|c|c|c|}
\hline IR-20 & 2.19 & 1.68 & 0.31 & 1.91 & 1.38 & 1.89 & 1.93 & 0.15 & 0.37 & 0.7 & 1.33 & 5.82 & 7.35 & 0.33 & 0.51 & 0.62 & 1.75 \\
\hline Average & 3.43 & 2.28 & 0.70 & 2.77 & 2.00 & 2.70 & 2.85 & 0.32 & 0.90 & 1.00 & 1.52 & 5.00 & 16.8 & 0.32 & 0.48 & 0.86 & 1.58 \\
\hline
\end{tabular}

Note: YP and YS are grain yields (t/ha) under non-stressed, and under moderately stressed conditions (SL2 0.34) respectively.

Table 3. Spearmen's correlation coefficients between YP, YS and drought tolerance indices determined across 40 rice genotypes at the SL2 0.34 stress level.

\begin{tabular}{|c|c|c|c|c|c|c|c|c|c|c|c|c|c|c|c|c|c|}
\hline & $\mathrm{YP}$ & YS & STI & GMP & MRP & HARM & MP & REI & ATI & $\mathrm{YI}$ & MSTIK1 & SNPI & SSPI & YSI & RDI & SSI & MSTIK2 \\
\hline YS & 0.71 & & & & & & & & & & & & & & & & \\
\hline STI & 0.92 & 0.91 & & & & & & & & & & & & & & & \\
\hline GMP & 0.92 & 0.91 & 1.00 & & & & & & & & & & & & & & \\
\hline MRP & 0.93 & 0.91 & 1.00 & 1.00 & & & & & & & & & & & & & \\
\hline HARM & 0.88 & 0.95 & 0.99 & 0.99 & 0.99 & & & & & & & & & & & & \\
\hline MP & 0.96 & 0.87 & 0.99 & 0.99 & 0.99 & 0.97 & & & & & & & & & & & \\
\hline REI & 0.86 & 0.32 & 0.64 & 0.64 & 0.65 & 0.58 & 0.71 & & & & & & & & & & \\
\hline ATI & 0.88 & 0.87 & 0.96 & 0.96 & 0.95 & 0.97 & 0.95 & 0.67 & & & & & & & & & \\
\hline $\mathrm{YI}$ & 0.66 & 0.02 & 0.38 & 0.37 & 0.38 & 0.30 & 0.46 & 0.94 & 0.41 & & & & & & & & \\
\hline MSTIK1 & 0.66 & 0.02 & 0.38 & 0.37 & 0.38 & 0.30 & 0.46 & 0.94 & 0.41 & 1.00 & & & & & & & \\
\hline SNPI & -0.68 & -0.04 & -0.40 & -0.39 & -0.40 & -0.32 & -0.48 & -0.94 & -0.44 & -1.00 & -0.99 & & & & & & \\
\hline SSPI & 0.83 & 0.27 & 0.60 & 0.60 & 0.61 & 0.53 & 0.68 & 1.00 & 0.63 & 0.96 & 0.96 & -0.96 & & & & & \\
\hline YSI & 0.16 & -0.50 & -0.16 & -0.16 & -0.16 & -0.23 & -0.07 & 0.57 & -0.10 & 0.80 & 0.80 & -0.78 & 0.62 & & & & \\
\hline RDI & 0.16 & -0.50 & -0.16 & -0.16 & -0.16 & -0.24 & -0.07 & 0.57 & -0.10 & 0.80 & 0.80 & -0.77 & 0.62 & 1.00 & & & \\
\hline SSI & 0.66 & 0.02 & 0.38 & 0.37 & 0.38 & 0.30 & 0.46 & 0.94 & 0.41 & 1.00 & 1.00 & -0.99 & 0.95 & 0.80 & $\begin{array}{l}0.80 \\
-\end{array}$ & & \\
\hline MSTIK2 & -0.66 & -0.02 & -0.38 & -0.37 & -0.38 & -0.30 & -0.47 & -0.94 & -0.42 & -1.00 & -1.00 & 0.99 & -0.96 & -0.80 & 0.80 & -1.00 & \\
\hline
\end{tabular}

Notes: YP and YS are grain yields (t/ha) under non-stressed, and under moderately stressed conditions (SL2 0.34) respectively.
Bold numbers are significant at 5\% significance level. 
PMK-01) were reported to be moderately resistant or resistant/highly resistant to one or multiple races of the blast disease fungus Pyricularia grisea (Mau et al., 2018). Thus, these genotypes could be used as parents for the development of high yielding, blast resistant, drought tolerant varieties of pigmented upland rice or could be recommended for direct release as new varieties.

\section{Materials and methods}

\section{Research location}

This research was carried out in the Field Agriculture Laboratory of Universitas Nusa Cendana, Kupang, East Nusa Tenggara, Indonesia during the dry season (June to October) 2017. The research site was located at $10.15432 \mathrm{~S}$ Latitude and 123.66997 East Longitude, about $110 \mathrm{~m}$ above sea level (asl). The soil type of the research site was an Entisol (Vertisol: USDA).

\section{Experimental design}

Evaluation of drought tolerance was carried out during the dry season to allow an appropriate setting for imposition of drought stress. The experiment employed a Split Plot design consisting of irrigation level (I) as the main plots and upland rice genotypes $(G)$ as the subplot treatments. The main plots consisted of three irrigation levels, i.e. $\mathrm{I}_{0}$ : irrigation at an optimum level (100\% Field Capacity), $\mathrm{I}_{1}$ : irrigation at $75 \%$ field capacity level and $\mathrm{I}_{2}$ : irrigation at $50 \%$ field capacity. Subplot treatments consisted of 40 rice genotypes.

In the normal/non-stressed treatment $(100 \% \mathrm{FC})\left(I_{0}\right)$, the plants were watered daily to maintain the soil at field capacity from the time of planting until harvest. In the moisture-stressed treatments, the plants were irrigated on a daily basis to maintain soil at $100 \%$ field capacity level from the time of planting until the initial flowering stage, followed by reduced irrigation to either a $75 \% \mathrm{FC}$ level $\left(\mathrm{I}_{1}\right)$ or a $50 \% \mathrm{FC}$ level $\left(I_{2}\right)$ from the early flowering stage until harvest. Irrigations were based on calculated water loss through evapotranspiration based on assumed mean $\mathrm{Et}_{0}$ values in the research area estimated over the previous five years (5.24 $5.28 \mathrm{~mm} \mathrm{day}^{-1}$ during July to October) and the assumed values for the Kc coefficient of rice plants during the flowering and reproductive stage (1.1).

\section{Plant materials}

The research materials used in the study were 40 upland rice genotypes consisting of 37 local cultivars of red and black rice from East Nusa Tenggara Province in Indonesia along with three check cultivars kindly provided by the Indonesian Rice Research Institute, i.e. Aek Sibundong (Indonesian released superior red rice variety), Gajah Mungkur (drought tolerant variety) and IR20 (drought susceptible variety). All treatments consisted of two replicates, and in total, 80 experimental units were observed per irrigation main-plot and 240 units in all combined main-plot and sub-plots.

\section{Plant cultivation}

The planting field was first cleared, and a total of 240 plots of $2 \mathrm{~m} \times 2 \mathrm{~m}$ size were prepared for growing the rice plants.
These 240 plots were arranged in two replicates of the main plot treatment, each consisted of 120 plots (80 plots for each of three irrigation level). All the treatments were placed randomly, starting from the main-plot treatment followed by placement of sub-plot treatment within each of the assigned main-plot treatments. Between sub-plot spacing was $50 \mathrm{~cm}$, and between main-block spacing was 1.0 $\mathrm{m}$.

The plots were irrigated until field capacity level before planting the rice seeds. Rice seeds were planted manually in planting holes of $20 \mathrm{~cm} \times 25 \mathrm{~cm}$ plant spacing. Three seeds were planted in each planting hole, and only one plant per hole was retained for the evaluation. Irrigation was done according to the assigned treatments.

The rice plants were provided with Urea, SP36, and $\mathrm{KCl}$ as basal fertilizers at a rate of, respectively, $80 \mathrm{~g} / 4 \mathrm{~m}^{2}$ sub-plot (equal to $200 \mathrm{~kg} \mathrm{ha}^{-1}$ ), $60 \mathrm{~g} / 4 \mathrm{~m}^{2}$ sub-plot (equal to $150 \mathrm{~kg} \mathrm{ha}$ ${ }^{1}$ ), and $40 \mathrm{~g} / 4 \mathrm{~m}^{2}$ sub-plot (equivalent to100 $\mathrm{kg} \mathrm{ha}^{-1}$ ). SP36 and $\mathrm{KCL}$ were applied at planting time while Urea was applied twice at planting time and 45 days after planting.

\section{Observation and data analysis}

The main observed variable was dry grain weight per $4 \mathrm{~m}^{2}$ sub-plot which then was converted into grain yield/ha ( $\mathrm{t}$ ha $\left.{ }^{1}\right)$. The grain yields in non-stressed and stressed treatments included YS (potential yield of given genotype under stress condition), YP (potential yield of a given genotype under nonstressed condition), Y.S (average yield of all genotypes under stress condition) and Y.P (average yield of all genotypes under non-stressed condition). The grain yield data were then used to calculate drought tolerance indices SSI (Fischer and Maurer, 1978); RDI (Fischer and Wood, 1979); MP (Rosielle and Hamblin, 1981), DRI (Bidinger et al., 1987); STI and GMP (Fernandez, 1992); REI and MRP (Hossain et al., 1999); MISTIK1 and MSTIK2 (Farshadfar and Sutka, 2002); ATI, SSPI, and SNPI (Moosavi et al., 2008); HARM (Dadbakhsh et al., 2011); and RDY (Farshadfar and Elyasi, 2012).

Calculated grain yield and drought tolerance index data were then subjected to analysis of variance to determine the treatment effects. The accumulated data were then subject to correlation analysis and Principal Component Analysis (Farshadfar and Elyasi, 2012, Ali and El-Sadek, 2016; Bennani et al., 2017). ANOVA was performed using GenStat version 12 software (VSNi, 2009) while correlation analysis and Principal Component Analysis were performed using PAST (Hammer et al., 2001).

\section{Conclusion}

Among fifteen drought-tolerance indices evaluated, STI, GMP, MRP, HARM, REI, ATI, YI, SNPI were considered to be the most effective for selection of drought tolerant, high yielding upland rice genotypes. The genotypes HK-07, ADN04, PMK-01, ADN-05, NGR-022, ALR-02, HK-06, and KMD-01 were selected as superior upland rice genotypes based on the chosen indices. The selected genotypes are recommended to be used as parents in a breeding program for improvement of drought tolerance and grain yield of upland rice varieties, in particular pigmented upland rice. 


\section{Acknowledgements}

We would like to thank the Directorate of Research and Community Services (DRPM), of the Indonesian Ministry of Research, Technology and Higher Education for financially supporting this research through Hibah Penelitian Terapan Unggulan Perguruan Tinggi 2017-2018. We also thank Andreas Bouk and Oktovianus Kehi Asa for the technical assistance they provided in the field.

\section{References}

Abenavoli MR, Leone M, Sunseri F, Bacchi M, Sorgona A (2016) Root phenotyping for drought tolerance in bean landraces from Calabria (Italy). J Agron Crop Sci. 202(1): 112.

Ali MB, El-Sadek A (2016) Evaluation of drought tolerance indices for wheat (Triticum aestivum L.) under irrigated and rainfed conditions. Communication in Biometry and Crop Science. 11(1): 77-89.

Alonso-Blanco C, Aarts MGM, Bentsink L, Keurentjes JJB, Reymond M, Vreugdenhil D, Koornneef M (2009) What has natural variation taught us about plant development, physiology, and adaptation? Plant Cell. 21(7): 1877-1896.

Anower MR, Boe A, Auger D, Mott IW, Peel MD, Xu L, Kanchupati P, Wu YJ (2015) Comparative drought response in eleven diverse alfalfa accessions. J Agron Crop Sci. 203: 1-13.

Bahar B, Yildirim M (2010) Heat and drought resistances criteria in spring and bread wheat: drought resistance parameters. Sci Res Essays. 5(13): 1742-1745.

Bennani S, Nsarellah N, Jlibene M, Tadesse W, Birouk A, Ouabbou H (2017) Efficiency of drought indices under different severities for bread wheat selection. Aust J Crop Sci. 11(4): 395-405.

Bidinger FR, Mahalakshmi V, Rao GDP (1987) Assessment of drought resistance in pearl millet (Pennisetum americanum (L) Leeke). I. Factors affecting yields under stress. Aust J Agr Sci. 38: 37-48.

Bray EA, Bailey-Serres J, Weretilnyk E (2000) Responses to abiotic stresses. In: Gruissem W, Buchannan B, Jones R. Biochemistry and Molecular Biology of Plants. Maryland, USA: ASPP SYMP P. 1158-1249.

Dadbakhsh A, Yazdansepas A, Ahmadizadeh M (2011) Study drought stress on yield of wheat (Triticum aestivum L.) genotypes by drought tolerance indices. Adv Environ Bio. 5(7): 1804-1810.

Dixit S, Singh A, Kumar A (2014) Rice breeding for high grain yield under drought: a strategic solution to a complex problem. International Journal of Agronomy. 2014, Article ID 863683.

Farooq M, Kobayashi N, Ito O, Wahid A, Serraj R (2010) Broader leaves result in better performance of indica rice under drought stress. J Plant Physiol. 167(13): 1066-1075.

Farshadfar E, Sutka J (2002) Multivariate analysis of drought tolerance in wheat substitution lines. Cereal Res Commun. 31: 33-40.

Farshadfar E, Elyasi P (2012) Screening quantitative indicators of drought tolerance in bread wheat ( $T$. aestivum) landraces. Eur J Exp Biol. 2 (3): 577-584.

Fernandez GCJ (1992) Effective selection criteria for assessing plant stress tolerance. In: Kuo CG (ed) Adaptation of food crops to temperature and water stress.
Proceeding of an Int. Symp. AVRDC-Inst. of Botany, Taiwan. 257-270.

Fischer RA, Maurer R (1978) Drought resistance in spring wheat cultivar: I. Grain yield response. Aust J Agric Res. 29:897-912.

Fischer RA, Wood JT (1979) Drought resistance in spring wheat cultivars III. Yield association with morphological traits. Aust J Agr Res. 30:1001-1020.

Fukai S, Cooper M (1995) Development of drought-resistant cultivars using physio-morphological traits in rice. Field Crops Res. 40(2): 67-86.

Golabadi M, Arzani A, Mirmohammadi Maibody SAM (2006) Assessment of drought tolerance in segregating populations in durum wheat. Afr J Agric Res. 1(5):162-171.

Golbashy M, Ebrahimi M, Khorasani SK, Choukan R (2010) Evaluation of drought tolerance of some corn (Zea mays L.) hybrids in Iran. Afr J Agric Res. 5(19): 2714-2719.

Halliwell B (2006) Reactive species and antioxidants: redox biology is a fundamental theme of aerobic life. Plant Physiol. 141(2): 312-322.

Hammer O, Harper DAT, Ryan PD (2001) PAST: paleontological statistics software package for education and data analysis. Available from: https://palaeo electronica.org/2001_1/past/issue1_01.htm.

Hossain ABS, Sears AG, Cox TS, Paulsen GM (1999) Desiccation tolerance and its relationship to assimilate partitioning in winter wheat. Crop Sci. 30: 622-627.

Hyun JW, Chung HS (2004) Cyanidin and malvidin from Oryza sativa cv. Heugjinjubyeo mediate cytotoxicity against human monocytic leukemia cells by the arrest of $\mathrm{G} 2 / \mathrm{M}$ phase and induction of apoptosis. J Agric Food Chem. 52: 2213-2217.

IAARD (Indonesian Agency for Agricultural Research and Development) (2012) Newly released superior rice varieties. Warta Penelitian Pertanian. 34(1): 8-9. [Indonesian].

Ilker E, Tatar Ö, Aykut Tonk F, Tosun M, Turk J (2011) Determination of tolerance level of some wheat genotypes to post-anthesis drought. Turkish J Field Crops. 16(1):59-63.

Islam R, Mukherjee A, Hossain M (2012) Effect of osmopriming on rice seed germination and seedling growth. J Bangl Agric Univ. 10(1): 15-20.

Jafari A, Paknejad F, Jami Al-Ahmadi M (2009) Evaluation of selection indices for drought tolerance of corn (Zea mays L.) hybrids. Int J Plant Prod. 3(4): 33-38.

Kumar R, Sreenu K, Singh N, Jain N, Singh NK, Rai V (2015) Effect of drought stress on contrasting cultivars of rice. Int J Trop Agric. 33(2): 1559-1564.

Kumbhar SD, Kulwal PL, Patil JV, Sarawate CD, Gaikwad AP, Jadhav AS (2015) Genetic diversity and population structure in landraces and improved rice varieties from India. Rice Sci. 22(3): 99-107.

Mau YS, Ndiwa ASS and Arsa IGBA (2014) Drought tolerance of Local Rote and check varieties of groundnut (Arachis hypogaea L.) during dry season in two locations in East Nusa Tenggara. Agrivita. 36 (3): 268-277.

Mau YS, Ndiwa ASS, Markus JER, Oematan SS, Nasution A, Handoko DD, Makbul K (2017) Genetic diversity of red and black upland rice accessions from East Nusa Tenggara, Indonesia as revealed by agro-morphological characters. Biodiversitas 18(1): 197-211. 
Mau YS, Ndiwa ASS, Markus JER Oematan SS, Nasution A, Handoko DD, Makbul K (2018) Blast resistance levels of red and black upland rice local cultivars from Indonesia. Asian J Crop Sci. 10(2): 53-65.

Mishra SS, Panda D (2017) Leaf traits and antioxidant defense for drought tolerance during early growth stage in some popular traditional rice landraces from Koraput, India. Rice Sci. 24(4): 207-217.

Mitra J (2001) Genetics and genetic improvement of drought resistance in crop plants. Curr Sci India. 80: 758-762.

Moosavi SS, Samadi YB, Naghavi MR, Zali AA, Dashti $H$, Pourshahbazi A (2008) Introduction of new indices to identify relative drought tolerance and resistance in wheat genotypes. Desert. 12: 165-178.

Naghavi et al

Nam SH, Choi, SP Kang MY, Koh HJ, Kozukue N, Friedman M (2006) Antioxidative activities of bran from twenty-one pigmented rice cultivars. Food Chem. 94: 613 - 620.

Pandey V, Shukla A (2015) Acclimation and tolerance strategies of rice under drought stress. Rice Sci. 22(4): 147-161.

Purbajanti ED, Kusmiyati F, Fuskhah E (2017) Growth, yield and physiological characters of three types of Indonesian rice under limited water supply. Asian J Plant Sci. 16: 101108.

Rahman MT, Islam MT, Islam MO (2002) Effect of water stress at different growth stages on yield and yield contributing characters of transplanted Aman rice. Pak J Biol Sci. 5(2): 169-172.

Rosielle AA, Hamblin J (1981) Theoretical aspects of selection for yield in stress and non-stress environments. Crop Sci. 21: 943-946.

Santika A, Rozakurniati (2010) Evaluation technique of rice quality of several glutinous and red upland rice. Buletin Teknik Pertanian. 15(1): 1-5. [Indonesian]
Sarkar RK, Mahata KR, Singh DP (2013) Differential responses of antioxidant system and photosynthetic characteristics in four rice cultivars differing in sensitivity to sodium chloride stress. Acta Physiol Plant. 35(10): 2915-2926.

Shao Y, Zhang G, Bao J (2011) Total phenolic content and antioxidant capacity of rice grains with extremely small size. Afr J Agric Res. 6(10): 2289-2293.

Singh B, Reddy KR, Redoña ED, Walker T (2017a) Developing a screening tool for osmotic stress tolerance classification of rice cultivars based on in vitro seed germination. Crop Sci. 57(1): 387-394.

Singh B, Reddy KR, Redoña ED, Walker T (2017b) Screening of rice cultivars for morpho-physiological responses to early-season soil moisture stress. Rice Sci. 24(6): 322-335.

Sio-Se MA, Ahmadi A, Poustiniand K, Mohammadi V (2006) Evaluation of drought resistance indices under various environmental conditions. Field Crop Res. 98: 222-229.

Swapna S, Shylaraj KS (2017) Screening for osmotic stress responses in rice varieties under drought condition. Rice Sci. 24(5): 253-263.

Toorchi M, Naderi R, Kanbar A, Shakiba MR (2012) Response of spring canola cultivars to sodium chloride stress. Ann Biol Res. 2(5): 312-322

Tsuda T, Horio F, Osawa T (2002) Cyanidin 3-O-betaglucoside suppresses nitric oxide production during a zymosan treatment in rats. J Nutr Sci Vitaminol. 48: 305310.

VSN International (2009) GenStat $12^{\text {th }}$ Edition for Windows. VSN International Ltd. www.vsni.uk.

Yue B, Xue WY, Xiong LZ, Yu XQ, Luo LJ, Cui KH, Jin DM, Xing $Y Z$, Zhang QF (2006) Genetic basis of drought resistance at reproductive stage in rice: separation of drought tolerance from drought avoidance. Genetics. 172(2): 1213-1228. 